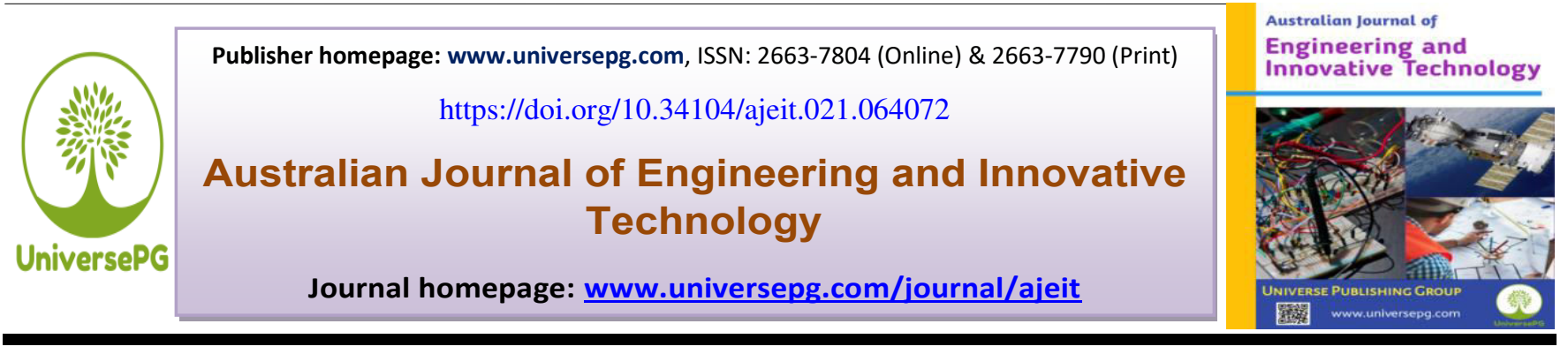

\title{
Household Waste Management in Formal Housing Developments in Afghanistan: A Case Study of Kabul City
}

\author{
Asghar Ghaforzai ${ }^{1}$, Sajid Ullah ${ }^{2}$ and Muhiburahman Asir $^{3}$ \\ ${ }^{1 \& 2}$ Department of Water and Environmental Engineering, Nangarhar University, Jalalabad, Afghanistan; and ${ }^{3}$ Department of \\ Civil Engineering, Nangarhar University, Jalalabad, Afghanistan. \\ *Correspondence: asghar.ghaforzai2@gmail.com (Asghar Ghaforzai, Department of Water and Environmental Engineering, \\ Nangarhar University, Jalalabad, Afghanistan).
}

\begin{abstract}
This study investigated the management of household solid waste in Kabul city, a planned urban city in Kabul Province, Afghanistan. The study involved assessment of waste quantification and composition, handling, collection and disposal as well as public concern and attitude towards waste management. A questionnaire survey was conducted from 270 households (10\%) selected on the basis of stratified random sampling. Quantification/composition was determined by manually sorting and weighing daily waste from sampled households using standard method ASTM-D5231-92. Solid waste generated per capita was $0.557 \pm 0.138$ kilograms per capita per day $(\mathrm{kg} / \mathrm{c} / \mathrm{d})(\mathrm{SD}=0.138)$ and $(3.75 \pm 0.33$ kilograms per household per day $(\mathrm{kg} / \mathrm{h} / \mathrm{d})$ whereas the total waste generation from Kabul city was estimated at 9.5 tons/d with a major fraction of food waste $(92.5 \%)$ followed by glass $(1.8 \%)$, metal and yard waste $(1.6 \%$ each), paper $(1.4 \%)$ and plastic $(1.1 \%)$ insight income families. Nearly one-third of the households had no storage and practiced open disposal in street sand empty plots. Waste collection by municipal authority was unsystematic and random with daily collection from only $10 \%$ of the households mostly using donkey carts. Key issues of public concern were improper solid waste management, waste burning, pollution of water bodies, disposal in empty plots and streets and open dumping. Public awareness about solid waste issues was high however only $15 \%$ showed willingness to pay for waste management.
\end{abstract}

Keywords: Household waste, Waste managemen, Public attitude, Kabul city, Waste composition and Collection.

\section{INTRODUCTION:}

Household solid waste (HSW) generation in urban areas is a growing problem in the South Asian countries like Afghanistan faced with increasing rate of urbanization and population growth of $2.4 \%$ (Mack et al., 2013). A rise in economic growth and standard of living further aggravate the situation with higher consumption of resources resulting in increased production of solid waste. Globally, annual municipal solid waste generation was projected to increase up to UniversePG I www.universepg.com
2.2 billion tons/year by the year 2025 (Hoornweg and Bhada-Tata, 2012). In Afghanistan, it was estimated to increase by more than two-fold from 18.4 million tons/year in 2009 to 39.9 million tons/year in 2025 (Hoornweg and Bhada-Tata, 2012; Batool and Ch, 2009). Management of such higher waste quantities is an area of increased environmental and public concern since if not managed well, HSW can have ecological and human health implications such as contamination of surface and groundwater, air pollution, soil conta- 
mination, vector borne diseases, odors and methane release from anaerobic decomposition (Al-Khatib et al., 2010; Ramachandra et al., 2018). Meanwhile, management of solid waste (SW) persists as a significant issue especially in fast growing urban areas of the developing nations. In developed countries, municipal solid waste management has evolved into an integrated system from prevention to final disposal and mainly driven by the increased concern for the environment, public health, resource conservation, climate change and community awareness (Marshall and Farahbakhsh, 2013). Developing countries are also faced with a sum of issues where the difficulties of handling SW are higher due to urbanization, class disparities, sociocultural aspects affecting the behaviors and underlying attitudes, policy weaknesses, governance issues and institutional mechanisms coupled with lack of financial and technical resources and public involvement (Marshall and Farahbakhsh, 2013; Ngoc and Schnitzer, 2009).

In South Asian countries like Afghanistan, HSW management principally comprises SW assortment and its removal (Wilson, 2007). However, SW is collected from only $60 \%$ of the houses and $90 \%$ of the collected waste is disposed of through open dumping (Mack et al., 2013). In the absence or partial management of SW, waste may be handled/managed at household level which is mainly centered on locating the waste elsewhere or reducing the quantity, often using unscientific and environmentally harmful techniques such as open burning and dumping. The uncollected waste lies openly in streets, vacant spaces, roads, drains, communal dumps or natural depressions (Batool et al., 2008). Meanwhile, the composition, proportion of waste collected and coverage of management services within the same urban center is not uniform and depends upon the type of household development and economic status of the public (Shekdar, 2009). Urban settlements in Kabul Province mainly comprises of unplanned old cities and urban villages developed unsystematically without conscious measures that often times lack basic municipal amenities. Formal housing developments that are developed according to government rules and regulations (Sivam, 2003) have been started in the form of townships in the Kabul city in the last four

UniversePG I www.universepg.com decades. Such localities have provision of basic services like water supply, sewerage, communication, power etc. and SW management is comparatively more organized (Hossain et al., 2021).

While, the generation, composition and management of household SW in whole cities with all types of housing development has been stated in numerous researches, the quantification, characterization and management of HSW in formally developed societies in Afghanistan have received less attention. This research was carried out in the main city of Kabul to examine the type of HSW management practices in such communities. The research was particularly focused on the SW quantification and composition, treatment and removal at the domestic levels by the community and assessment of awareness, underlying attitude and behavior of the locals towards HSW and its proper management in the presence of the relatively higher literacy rate and better economic status compared to population in other zones of the Kabul city.

\section{MATERIALS AND METHODS:}

Study area description - Kabul city lies in the middle of the province, with an expected of total people of 5 million within 22 districts, with a total number of homes are $(694,756)$; commercial units $(70,720)$ and organizational units are (761) (CSO, 2018). A comprehensive map of research area is available in Fig 1.

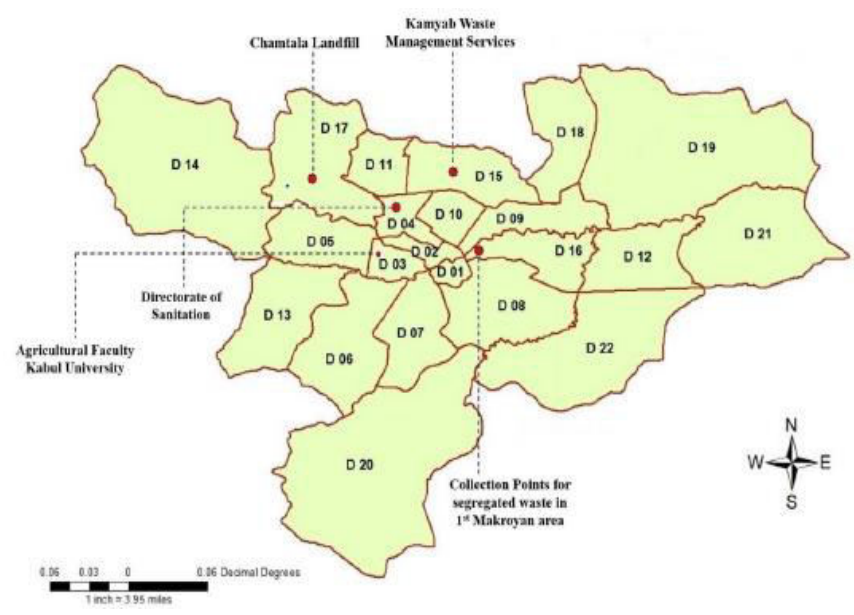

Fig 1: Study area Map (Kabul city).

Sampling and data collection - Data about household SWM was collected by applying the standard method ASTM D5231-92 and a questionnaire study using interview schedule from $10 \%$ of the households $(n=270)$ in Kabul city see Table 1. 
Table 1: Sampling design for household SW questionnaire survey in Kabul city.

\begin{tabular}{cccccc}
\hline Household type & \multicolumn{4}{c}{ Household solid Questionnaire Survey } \\
Residential & Locations & Samples/location & No. of samples & Sampling days & Total samples \\
High income & 18 & 05 & 90 & 01 & 90 \\
Middle income & 18 & 05 & 90 & 01 & 90 \\
Low income & 18 & 05 & 90 & 01 & 90 \\
Total & & & 270 & & 270 \\
\hline
\end{tabular}

Table 2: Sampling design for household SW amount survey in Kabul city.

\begin{tabular}{cccccc}
\hline Household type & \multicolumn{4}{c}{ Household solid waste amount survey } \\
Residential & Locations & Samples/location & No. of samples & Sampling days & Total samples \\
High income & 18 & 04 & 72 & 01 & 72 \\
Middle income & 18 & 04 & 72 & 01 & 72 \\
Low income & 18 & 04 & 72 & 01 & 72 \\
Total & & & 216 & & 216 \\
\hline
\end{tabular}

The selections of households were based on stratified random sampling technique by spatially dividing the research area into the existing sectors and then selecting random samples from each. The household sources were divided into low, medium and highincome level. Table 1 lists a total of 18 sampling locations for each source type, and SW sum to release ratio was considered. The data about households, number of persons per household, number of employees, house area etc. was collected from questionnaire survey. The respondents interviewed were mainly the head of families. The questionnaire survey included parameters such as SW storage and management at source, collection and disposal procedures, as well as community attitudes and concerns about SWM. General data about the respondents and the households was collected such as family size, house area and education level. Information collected on SW storage and source management considered the kind of waste storage bins, the place where waste is stored in the house and if any waste handling or processing is carried out at homes such as burning, burying, open dumping, recycling/reuse, composting and selling to vendors. The section on SW collection was used to determine whether or not there was a garbage collection program in place, as well as the facilities and frequency of SW collection, as well as the cost of SW management. The questionnaire also covered information about community attitude and awareness towards the issues and concern from the hazards of improper SW management.
Solid waste quantification and composition - The quantity of SW produced and its material composition was determined by using the standard method ASTM D5231-92 and also by collecting SW produced in a day from $9 \%$ of the houses $(n=216)$ in plastic bags and then the various components were manually sorted and weighed given in Table 2 (Di Maria et al., 2013; Suthar and Singh, 2015). The same stratified random sampling approach was adopted for the selected households from all the sectors. Household waste generation was determined by quantifying the SW produced at each household and then calculating the per capita generation rate $(\mathrm{kg} / \mathrm{capita} /$ day) by dividing the daily waste generated with the sum of members in the households. The relative proportion of each waste component was estimated as percent by weight on wet basis (Uddin et al., 2016; Di Maria et al., 2015).

\section{Composition of household waste}

Physical composition of waste: Physiochemical composition of household SW shows a vital role in selection of suitable municipal SWM approach (Ilyas et al., 2017). For physical composition analysis of household SW an organized selected disposal location away from winds was used where weighing and unloading of collected samples was completed. Examination of the physical composition of household solid waste a standard method ASTM-D5231-92 was applied (Management, 2008). This technique needs a representative sample of 100-200 $\mathrm{kg}$ from residential regions. Reduction technique was done for huge waste 
generation sources to get sample of almost $200 \mathrm{~kg}$ and for samples less than $200 \mathrm{~kg}$ segregation method was used directly. To make a representative sample, the waste sample was assorted carefully and then distributed into four piles of equal amount followed by elimination of two piles of waste at opposite ends and then mixing the remaining volume. When the sample was ready it was loaded in plastic container of 30 liters' volume and fallen down at ground several times from $30 \mathrm{~cm}$ height. Then the volume of household SW and weight was measured. The physical composition ratio of each SW sample in wet base, Xi (\%), was measured as follows.

$\mathrm{Xi}=($ Weight of each weight composition $(\mathrm{kg})) /($ Total amount of each west composition $(\mathrm{kg}))$ X $100 \ldots .$.

The samples were divided into 07 physical components on the basis of physical composition, as given in (Table 3).

Chemical composition of waste - Chemical composition analysis included carbon and nitrogen analysis, moisture content (MC) of household trash, and three component analysis in the current study. The same chemical composition analyses were performed by (Ilyas et al., 2017) and (Nadeem et al., 2016).

Data analysis - For SW production and composition, 95\% confidence interval of the means was calculated. Data analysis was done using Graph Pad Prism (Graph Pad Software, Inc., San Diego, CA, USA) and Microsoft Excel.

\section{RESULTS AND DISCUSSION:}

\section{Household solid waste generation and composition}

Average production of household SW per individual in Kabul city was $0.557 \pm 0.138 \mathrm{~kg} / \mathrm{d}(3.75 \pm 0.33 \mathrm{~kg} / \mathrm{day}$ per household) whereas the total waste generation from Kabul city was estimated at 9.5 tons/d. The SW was predominantly constituted by food waste found in a proportion of $92.5 \%$ indicating that consumption was preoccupied by fresh food products. This was followed by glass $(1.8 \%)$, metal $(1.6 \%)$, yard waste $(1.6 \%)$, paper $(1.4 \%)$ and plastic (1.1\%) for high income families (Fig 2). While this amount is not same for middle- and low-income families and we found some variations in their waste production as given in Table 3.

Table 3: Average household waste composition in Kabul city.

\begin{tabular}{lcccc}
\hline S. No & Physical components & $\begin{array}{c}\text { High income } \\
\text { Average \% }\end{array}$ & $\begin{array}{c}\text { Middle income } \\
\text { Average \% }\end{array}$ & $\begin{array}{c}\text { Low income } \\
\text { Average \% }\end{array}$ \\
01 & Food waste & 92.5 & 91.5 & 90.8 \\
02 & Bottles/ Glass & 1.8 & 1.7 & 1.7 \\
03 & Metal & 1.6 & 1.8 & 1.7 \\
04 & Yard waste & 1.6 & 1.8 & 2.2 \\
05 & Paper & 1.4 & 1.8 & 1.8 \\
06 & Plastic & 1.1 & 1.4 & 1.8 \\
07 & Total & 100 & 100 & 100 \\
\hline
\end{tabular}

The food waste included waste sourced from kitchen that was lost during the consumption of food and comprised of both the unavoidable food waste (mainly from vegetable and fruit peels/cores) and the avoidable unconsumed fraction. The higher proportion of food waste was mainly attributed to the occurrence of huge quantities of cores of locally grown seasonal honey melons and water melons that were consumed in higher amounts during the survey period due to their cheaper availability. Food waste was also higher due to consumption of food by the larger household size (average 7) usually living as joint family. Another reason for the higher food waste fraction was the

UniversePG I www.universepg.com absence of food waste grinders or disposers (a kitchen appliance) in the houses in Kabul city as well as in Afghanistan, in general. Food waste disposer's mechanically grinds and separate a considerable amount of waste from SW stream and discharge it into the sewage using tap water.

A study by (Marashlian and El-Fadel, 2005) found that food waste grinders can reduce the total SW generation by 12 to $43 \%$. Dry bread, came from the left over home cooked traditional bread (called "Dodai") that is prepared three times daily for the meals. Dry bread was separately characterized from food waste as it was not thrown with the SW but stored separately to dry- 
ness. Plastic mainly constituted post-consumer plastics (empty bottles, plastic objects from other products and plastic bags etc.). The type of glass material produced as waste was mainly flat glass used in windows etc. and glass from beverage and food containers. Metals in the waste included both ferrous and non-ferrous metals and commonly included empty soft drink cans.

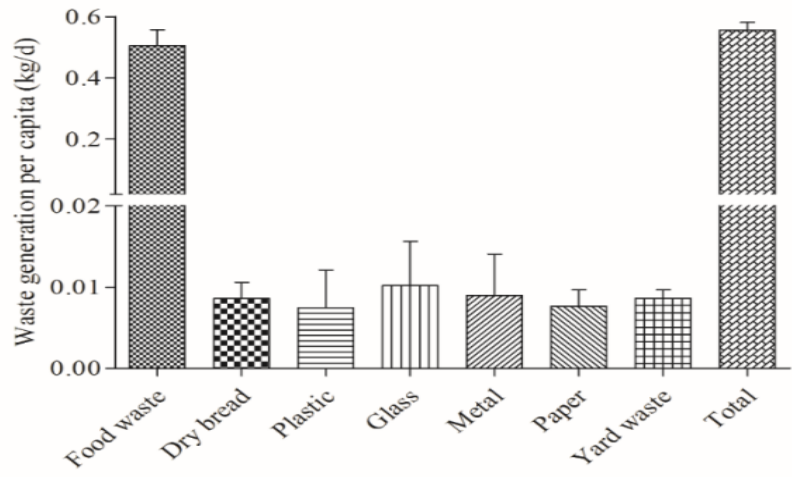

Fig 2: Solid waste composition and per capita generation $(\mathrm{kg} / \mathrm{d})$ (error bars indicate $95 \%$ confidence interval).

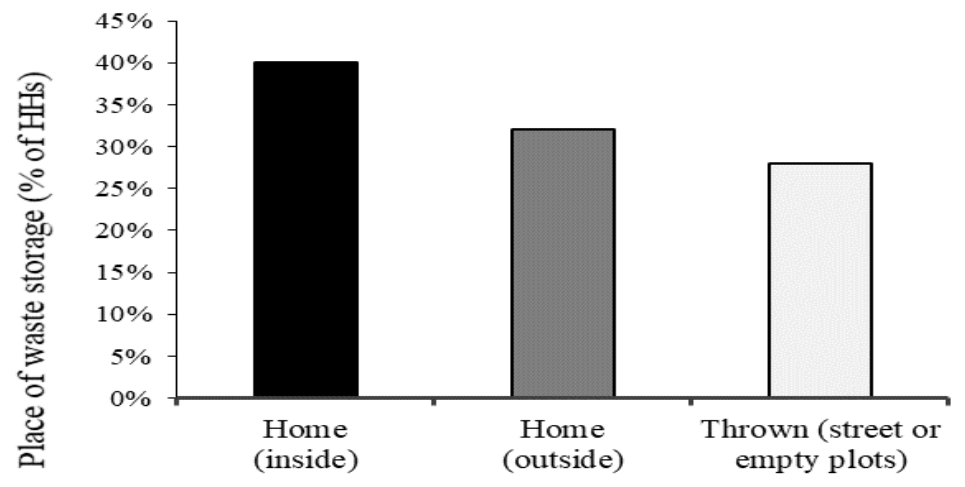

Fig 3: Waste storage: (a) place where waste stored; (b) mode of waste storage.

Waste management activities by households - The type of household waste generated in Kabul city was both organic and inorganic in nature with the organic fraction having the foremost part. The organic waste, as evident from the waste characterization was principally composed of the biodegradable fraction, mainly food waste. Hence, the waste was better suited for biological treatment. However, only $6 \%$ of the households were composting the food waste for application as soil conditioner and fertilizer for the gardens and locally grown vegetables (Fig 4). Majority of the people $(50 \%)$ dumped the waste in communal containers that lead to anaerobic degradation, foul odors and increased vectors at the dumped sites. Dry bread

UniversePG I www.universepg.com
Storage of household waste - Most of the households (40\%) stored the generated waste inside the home within their premises while $32 \%$ in the open within the house (Fig 3). It was peculiar to note that $28 \%$ of the households didn't store the generated waste in their homes but rather threw it in the street corners, empty plots or along the irrigation canal that flows on the eastern side of the Town. This practice was a source of nuisance to the people and causing blockage of drains and public health issues. Waste storage was practiced mostly in areas where communal containers were available and waste collection by the municipality was common. In the $72 \%$ households who practiced waste storage within their premises, open bins were commonly used (30\%) to store the waste while only $15 \%$ had closed bins. Others kept it in plastic bags (27\%) before being collected or openly disposed of (Fig 3). Separate bins were also kept by some of the households for organic (putrescible) and inorganic/ recyclable waste.

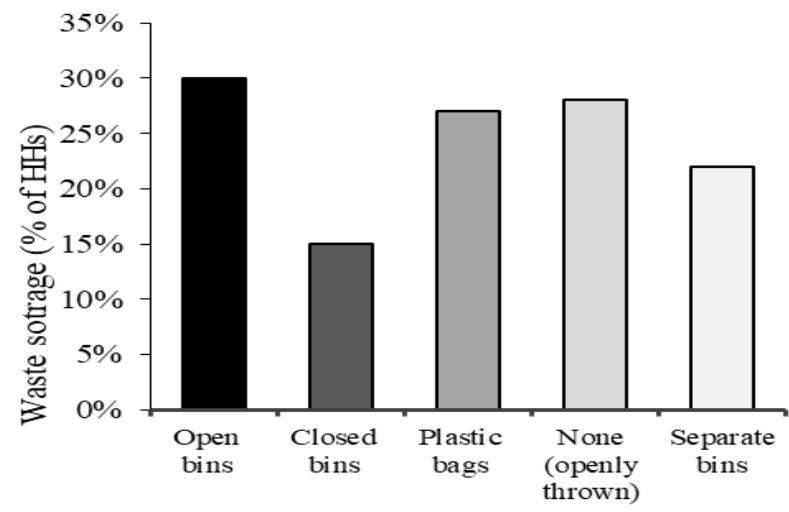

was not thrown with the food waste for religious and cultural reasons and income generation, and sold in the market (84\% households) at a price of about AFN $20 / \mathrm{kg}(0.25 \mathrm{USD} / \mathrm{kg})$. The rest were mainly using it as feed for livestock. Yard waste that constituted plant leaves, grasses, shrubs and small shoots etc. was also mainly thrown $(43 \%)$ in the communal containers or burnt (35\%) instead of biodegradation that was practiced only by $3 \%$ of the households.

For paper waste in Kabul city, except a fraction of population $(6 \%)$ who reused it, waste minimization practices were minimal. Paper was mainly disposed of directly into communal containers or opens dumps (47\%) and burnt (18\%) while 17\% sold it. On the other 
hand, newspaper was mostly sold in the market for reuse as packing material or recycling (64\% in total).

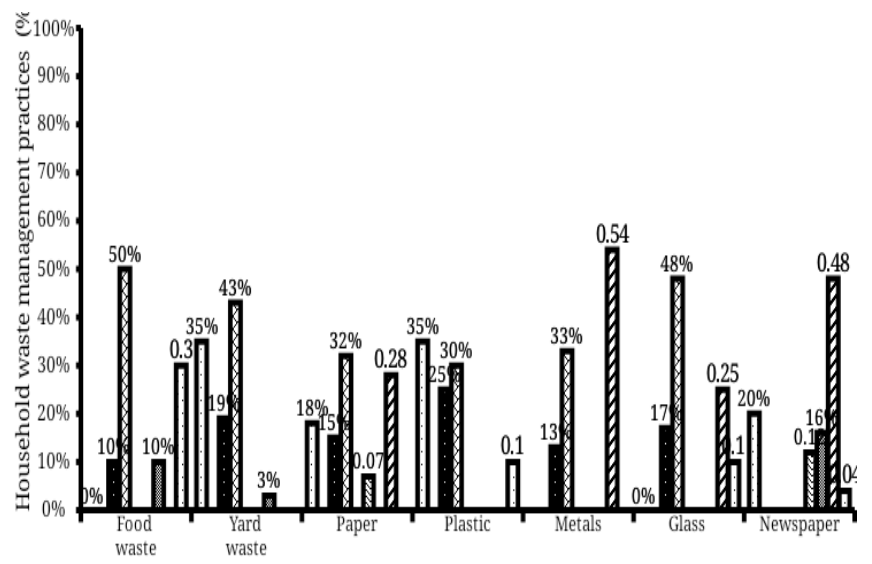

Fig 4: Household management and disposal practices for different waste components in Kabul city.

In case of plastic waste, which is of major environmental concern, environmentally unsafe practices were prevalent especially burning (Fig 4) causing air pollution in the area. Disposal of plastic to communal containers or open dumps was also common $(55 \%$ combined) while there was no mechanism for collection of plastic for recycling. Glass and metals, two common recyclable materials, were separated by $25 \%$ and $>50 \%$ of the households respectively were from the daily waste and selling it to vendors for reuse and recycling.

Household SW collection in Kabul city - Household waste collection system was present in Kabul city and was implemented by Kabul Municipality (KM). However, waste collection was not regular and inferquent. Waste was collected from each resident in donkey carts and taken either to communal containers or to the final dumping site. According to the survey, daily waste collection covered only $10 \%$ of the households. In most part of the city, waste was collected either on fortnightly (42\%) or weekly (38\%) basis, while in some areas $(8 \%)$, waste collection was carried out only once a month. The communal containers were placed at various sites in the Town sectors, which were transported to the dumping sites for emptying without any prior segregation (for reusable, recyclable, biodegradable material) and processing such as composting and combustion. The dumping site was a natural depression that was not properly designed and operated as a sanitary landfill but an open dump without taking

UniversePG I www.universepg.com into account the environmental considerations to protect groundwater from leachate and control odors and vectors while also polluting the air, water, and soil. Poor collection mechanism and waste lying in the open communal containers for days was also a source of nuisance, odor, disease vectors and unhygienic conditions. The survey revealed that majority of the people $(70 \%)$ was not satisfied with the existing waste collection mechanism. KM on its part attributed the improper waste management to lack of trained sanitary staff and meagre budgetary allocations. Residents in Kabul city were mostly not paying for the waste collection or management $(88 \%)$ neither was they willing to pay for the service as responded by $85 \%$ households (Fig 5). They were of the opinion that KM has already been allocated funds by the Government and have staff on payroll to provide this service. Apart for unwillingness to pay for SWM, most of the people also considered the Government to be entirely responsible for waste collection, storage and disposal. Only, 40\% agreed that SWM is a joint concern of both the KM and the people. Nevertheless, all the survey households agreed that they are part of the issue and can play a significant part in SWM for the prevention of human health risk and protection and conservation of environment.

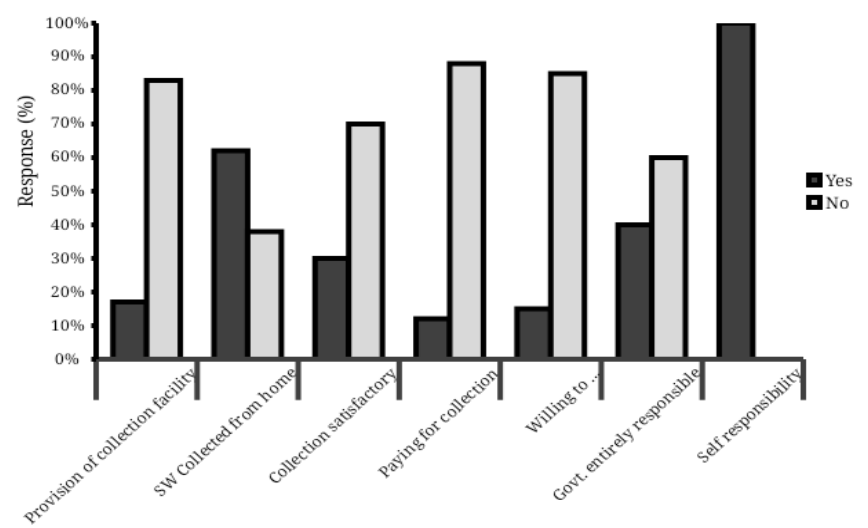

Fig 5: Solid waste collection from households.

Public attitude towards SWM - Attitudes and behavioral pattern of the community towards waste play a significant role in prevailing SW handling and management practices like waste storage, segregation, minimization, collection, and disposal. It also affect the overall functioning and implementation of SWM system and the willingness of the people to pay and contribute to SWM services (Marshall and Farahbakhsh, 2013). Such attitudes are largely governed by 
the cultural and socioeconomic status of the societies. Attitudinal response was assessed for different matters concerned with waste management such as the individual's own contribution, role and actions in dealing the issue, and the needed approaches to manage the problem. Overall, attitude appraisal on SWM revealed favorable feedback (Fig 6). Cognitive attitude concerning awareness about SW issues and its management was high as well as the level of concern. Likewise, predisposition of the behavior to respond to the issues was also mostly positive as people mostly wanted to play their role $(69 \%)$ in proper management of waste and abandoning practices that exacerbate the problem. They recognized that their choice of products for consumption is an issue in the amount of SW produced from the houses. A greater majority of the people agreed on the requirement for awareness and education at schools on environment and proper SWM. Opinion on KM role in managing the waste issues was mostly negative $(73 \%)$ whereas people consented to provision of facilities and adequate waste collection mechanism and instituting laws on reuse and recycling (waste minimization).

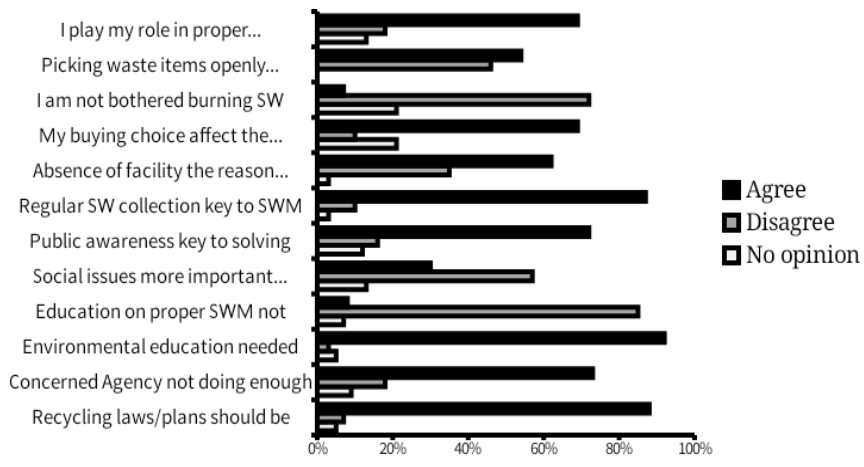

Fig 6: Public attitude towards solid waste management in Kabul city.

Concern about improper SWM - This section highlighted the level of concern to which the community was aware and recognized the hazards of improper SWM as an important aspect in the prevailing waste management practices. Ascertaining the level of concern was also important in view of the relatively higher literacy rate in Kabul city. People were mostly concerned about the issues from waste burning, disposal of waste to water bodies, open dumping, resource wastage and associated health risks (Fig 7). More than $80 \%$ were concerned about the burning of waste and associate health issues, pollution of rivers, streams and UniversePG I www.universepg.com groundwater from waste disposal, and the overall state of SWM in the city. About $50 \%$ to $75 \%$ of the respondents showed concern for the incidence of diseases due to poor storage and transfer methods of SW, choking of drains and the resulting flooding of streets, unsafe open dumping and illegal waste disposal in streets and plots and depletion of natural resources in the absence of any recycling/reuse program for the waste.

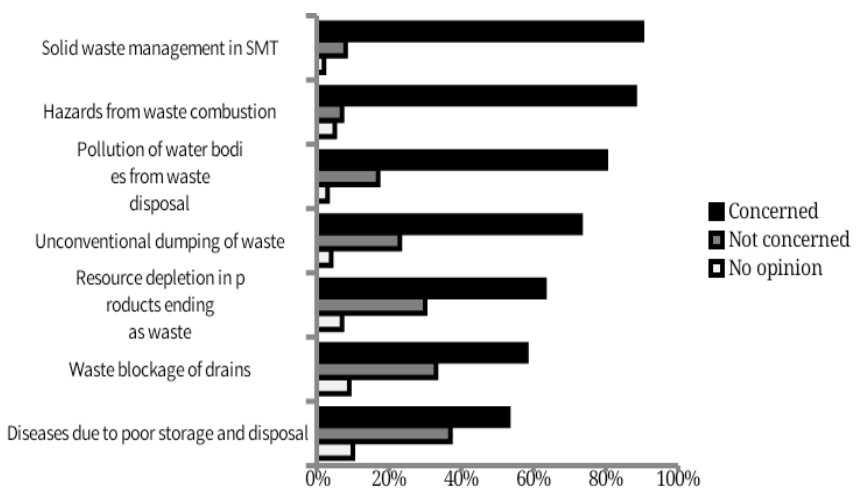

Fig 7: Level of public concern to solid waste management issues.

\section{CONCLUSION:}

Household SW generated at Kabul city principally constituted the biodegradable organic fraction, mainly food waste $(92.5 \%)$ while other constituents included yard waste, paper, plastic, metal and glass. Nearly one third of the population disposed of the waste openly to street or empty plots without any storage inside the house. Waste was not reduced or disposed of properly, for instance putrescible waste was not treated biologically, paper not collected for recycling, whereas plastic was burnt or disposed of openly. Waste collection by the concerned agency was not systematic and haphazard with daily collection covering only $10 \%$ of the households. This was causing increased environmental and health risks such as contamination of waters, blockage of drains and sewers and spread of diseases. Likewise, waste collection in donkey carts, storage in open communal containers and dumping openly on land was unsafe from an environmental and public health perspective and not approving by the local community. Lack of a properly devised SWM system, resources such as trained sanitary staff, financing, infrastructure, suitable planning were the main barriers in SWM. Concern of the people to the various SW issues was high and the attitudinal response to deal these issues was positive on the existing state of affairs, an inte- 
grated SWM system with a focus on waste is required. Minimization, provision of sufficient facilities to cover the entire population and sanitary landfills for final disposal of waste. Moreover, an increased awareness in the community is required to stop littering, burning and illegal disposal of waste openly. Also required is regular collection and sound institutional mechanism with increased allocation of financial and technical resources and setting up laws manage solid waste and prohibit illegal practices.

\section{ACKNOWLEDGEMENT:}

The authors received no financial support for the research, authorship or publication of this article.

\section{CONFLICT OF INTERESTS:}

The authors declare no conflict of interest.

\section{REFERENCES}

1) Al-Khatib et al. (2010). Solid waste characterization, quantification and management practices in developing countries. A case study: Nablus district-Palestine. J. of environmental management, 91(5), pp.1131-1138. https://doi.org/10.1016/j.jenvman.2010.01.003

2) ASTM Committee D-34 on Waste Management, (2008). Standard test method for determination of the composition of unprocessed municipal solid waste. ASTM International. https://doi.org/10.1177/0734242X08094624

3) Batool, S.A. and Ch, M.N. (2009). Municipal solid waste management in Lahore city district, Pakistan. Waste manage., 29(6), pp.1971-1981. https://doi.org/10.1016/j.wasman.2008.12.016

4) Batool et al. (2008). Economic potential of recycling business in Lahore, Pakistan. Waste management, 28(2), pp. 294-298. https://doi.org/10.1016/j.wasman.2006.12.007

5) Di Maria et al. (2015). Improvement of the management of residual waste in areas without thermal treatment facilities: A life cycle analysis of an Italian management district. Waste management, 44, pp.206-215. https://doi.org/10.1016/j.wasman.2015.07.012

6) Di Maria, F., Sordi, A. and Micale, C. (2013). Experimental and life cycle assessment analysis of gas emission from mechanically-biologically pretreated waste in a landfill with energy recovery. Waste Manage, 33(11), pp.2557-2567.

UniversePG I www.universepg.com
7) Hoornweg, D., Bhada-Tata, P. (2012). What a waste: a global review of solid waste management. http://hdl.handle.net/10986/17388

8) Hossain MR, Islam MA, and Hasan M. (2021). Assessment of medical waste management practices: a case study in Gopalganj Sadar, Bangladesh. Eur. J. Med. Health Sci., 3(3), 6271. https://doi.org/10.34104/ejmhs.021.062071

9) Ilyas et al. (2017). Waste generation rate and composition analysis of solid waste in Gujranwala City Pakistan. Int. J. Waste Resour, 7(3), p.97. https://doi:10.4172/2252-5211.1000297

10) Mack, T.J. (2018). Groundwater Availability in the Kabul Basin, Afghanistan. In Groundwater of South Asia (pp. 23-35). Springer, Singapore. https://doi.10.1007/978-981-10-3889-1 2

11) Marashlian, N. and El-Fadel, M. (2005). The effect of food waste disposers on municipal waste and wastewater management. Waste management \& research, 23(1), pp.20-31. https://doi.org/10.1177/0734242X05050078

12) Marshall, R.E. and Farahbakhsh, K. (2013). Systems approaches to integrated solid waste management in developing countries. Waste management, 33(4), pp.988-1003. https://doi.org/10.1016/j.wasman.2012.12.023

13) Nadeem, K., Farhan, K. and Ilyas, H. (2016). Waste amount survey and physio-chemical analysis of municipal solid waste generated in Gujranwala-Pakistan. International Journal of Waste Resources, 6(1), pp.196-204. http://dx.doi.org/10.4172/2252-5211.1000196

14) Ngoc, U. N. and Schnitzer, H. (2009). Sustainable solutions for solid waste management in Southeast Asian countries. Waste management, 29(6), pp.1982-1995. https://doi.org/10.1016/j.wasman.2008.08.031

15) Ramachandra, T.V., Bharath, H.A., Kulkarni, G. and Han, S.S. (2018). Municipal solid waste: Generation, composition and GHG emissions in Bangalore, India. Renewable and Sustainable Energy Reviews, 82, pp.1122-1136. https://doi.org/10.1016/j.rser.2017.09.085

16) Shekdar, A.V. (2009). Sustainable solid waste management: An integrated approach for Asian countries. Waste manage, 29(4), pp.1438-1448. https://doi.org/10.1016/j.wasman.2008.08.025 
17) Sivam, A. (2003). Housing supply in Delhi. Cities, 20(2), pp.135-141. https://doi.org/10.1016/S0264-2751(02)00121-X

18) Suthar, S. and Singh, P. (2015). Household solid waste generation and composition in different family size and socio-economic groups: A case study. Sustainable Cities and Society, 14, pp.5663. https://doi.org/10.1016/j.scs.2014.07.004

19) Uddin M. E., Ray S. K., and Ahammed T. (2017). Thermotolerant extracellular proteases produced by Bacillus subtilis isolated from local soil that representing industrial applications. $J$. of Pure and Applied Microbiol. 11(2), 733-741. https://doi.org/10.22207/JPAM.11.2.12

20) Wilson, D.C. (2007). Development drivers for waste management. Waste Management \& Research, 25(3), pp.198-207.

https://doi.org/10.1177/0734242X07079149

Citation: Ghaforzai A, Ullah S, and Asir M. (2021). Household waste management in formal housing developments in Afghanistan: a case study of Kabul city. Aust. J. Eng. Innov. Technol., 3(4), 64-72.

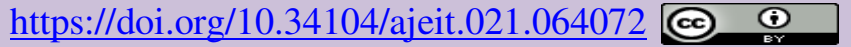

